on those with less power who argue for forward-looking change than on those who advocate maintaining embedded power structures or a return to earlier class, gender, sexuality, and race relations. Finally, while our attention may be most often drawn to these sensational battles over politically charged speech, we should not forget that academic freedom is about much more than the rights to utter controversial statements in public lectures or through electronic means. It is, as organizations such as the AAUP have long argued, vital for teaching, for research, and for the existence of shared governance. Just as importantly, the mundane cases that don't attract attention are perhaps more prevalent than those that receive attention. Their existence and effects need to be understood.

doi: $10.1017 /$ heq.2018.19

\title{
Authoritarian Legacies and Higher Education in Uruguay
}

\section{Vania Markarian}

The authoritarian government installed in Uruguay in June 1973 sought to radically make over formal education at all levels. In the previous decade, local right-wingers, like their comrades around the world, had been pointing to professors and teachers as the culprits behind the "deviant" behavior of youth, including through countercultural rebellion or through a variety of leftist political projects. While the right sometimes blamed excessive "academic freedom" for these developments, they tended to use this and related expressions to defend their right to pursue their pedagogical or scientific agendas. They also used it to reject the politicization of academic projects, particularly within the Universidad de la República, Uruguay's only university at the time. This emphasis set the right-wingers apart from

\footnotetext{
Vania Markarian works at the Universidad de la República in Montevideo. She received her PhD from Columbia University and has taught at Queens CollegeCUNY, Princeton University, and Columbia University. Her publications on contemporary Latin American history include Left in Transformation: Uruguayan Exiles and the Latin American Human Rights Networks, 1967-1984 and Uruguay, 1968: Student Activism from Global Counterculture to Molotov Cocktails.
} 
those who criticized the institution as dated, massified, and impoverished but who were also concerned with keeping the university autonomous from the national government, extending the range of socially involved actions, and enhancing the participation of students, faculty, and alumni in its self-governing bodies.

The right-wing authoritarian takeover put an end to these and other related debates on the goals and characteristics of higher education systems in connection with social change. What were the main aims of the new authorities? Did they have a plan for thorough reform? Did their worry about the previous politicization of academic life translate into a clear-cut program according to their own definitions of "academic freedom"? This brief paper describes the battery of measures implemented in the early years of the authoritarian regime, with the goal of characterizing the Uruguayan dictators' course of action vis à vis the Universidad de la República.

A few months after the coup, the government took over the university and arrested the members of its main council. ${ }^{1}$ Academic activities were temporarily suspended, and university facilities were closed and placed under military custody. The rector, Samuel Lichtensztejn, and most of the deans and were detained on the spot. Many students and faculty members were imprisoned soon afterward and remained in prison for long periods. The government also banned student unions and other "illicit" associations. ${ }^{2}$

The rationale behind these decisions was crystal clear. The results of a recent search by security forces had revealed "subversive activities" within university buildings, found "materials and artifacts for direct conspiratorial action," and proved the "indoctrination of young students with Marxist ideology" and "incitations to armed struggle." 3 This narrative aimed at legitimizing the authoritarian takeover while also revealing a deep knowledge of the institution's internal functioning, with plenty of anecdotal evidence of earlier events in each school. The new regime explained that the threat had been building since the 1950s, a time during which the "absurd sovereignty" of the university from the central government had put it at the service of "plain and simple subversives." Alleged violations of standard definitions of "academic freedom" included "agitating within schools," naming classrooms after such icons of the left as Ernesto "Che" Guevara, pushing aside faculty and students who were "true democrats," and pouring "Marxist content" into classes and curricula. In addition,

\footnotetext{
${ }^{1}$ Decreto 921/973, Oct. 28, 1973, Registro Nacional de Leyes y Decretos, $1482-$ 4 (hereafter cited as RNLD).

${ }^{2}$ Decreto 1026/973, Nov. 28, 1973, RNLD, 1665-71.

${ }^{3}$ Decreto 1026/973, Nov. 28, 1973.
} 
this self-justifying account pointed to the student movement's involvement in previous authorities' efforts to revamp the institution and engage in social actions aimed at promoting "national development," which had threatened the traditional power scheme of federated professional schools. ${ }^{4}$

The reanimation of arguments between current and former hegemonic groups lent an air of vengeance to the repressive measures implemented in the months following the authoritarian government's intervention. ${ }^{5}$ Swift action was taken to remove Lichtensztejn and the deans. ${ }^{6}$ Ad hoc attorneys led summary trials using "evidence" provided by military and police intelligence agencies, including pictures of walls with political graffiti or propaganda found in desks and bookshelves, and often charging deans and department chairs for the activities of students and professors they supervised. ${ }^{7}$ Another cause of dismissal in this early period was massive refusal to pledge allegiance to the new government according to rules imposed in mid-1974. ${ }^{8}$ It is difficult to arrive at precise numbers of politically motivated dismissals. Public denunciations at the time and dossiers put together after the end of the authoritarian period suggest that about 45 percent of the faculty was discharged. ${ }^{9}$ Official records reveal a total of 984 case files citing different reasons for dismissal between 1973 and 1984, peaking in 1974. ${ }^{10}$ Many of these academics where jailed and many more fled into exile in subsequent years.

\footnotetext{
${ }^{4}$ República Oriental del Uruguay, Junta de Comandantes en Jefe, Las Fuerzas Armadas al Pueblo Oriental vol. 2 (Montevideo, URY: Fuerzas Armadas Uruguayas, 1978), 30-39, 163-81.

${ }^{5}$ Vania Markarian, María Eugenia Jung, and Isabel Wschebor, 1983: La generación de la primavera democrática (Montevideo, URY: Archivo General, Universidad de la República, 2008), 11-27. In this case, current hegemonic groups means authorities appointed by the authoritarian government; former hegemonic groups refers to the left of the center groups that tried to reform the institution before 1973 .

${ }^{6}$ Expediente 11955/73, box 15, folder 6; and Expediente 1053/74, box 35, folder 18, in Fondo de la Dirección General Jurídica Archivo General de la Universidad de la República, Montevideo (hereafter DGJ, AGU).

${ }^{7}$ For example, Expedientes 1157/73, box 8, folder 6; 11955/73, box 6, folder 10; $1053 / 74$, box 35 , folder 18 ; and $8177 / 74$, box 8 , folder 5 , DGJ, AGU. See also Jimena Alonso and Alvaro Rico, Investigación histórica sobre la dictadura y el terrorismo de Estado en el Uruguay, 1973-1985 vol. 3 (Montevideo, URY: Ediciones Cruz del Sur-CEIU, 2008), 287-345.

${ }^{8}$ Decreto 351/974, May 7, 1974; Ley 14248/974, July 30, 1974, RNLD, 1325 and 308; and Circulares 184/74 and 185/74, Nov. 11, 1974, Archivo General, Universidad de la República (hereafter cited as AGU). For attempts to circumvent this ruling, see claim by Julio Ricaldoni, Aug. 3, 1974, box 1, folder 2, Archivo Ricaldoni, AGU. See also digest in box 24, folder 13, DJG, AGU.

${ }^{9}$ Enrique Kirberg, Uruguay: Transición democrática en la Universidad (Santiago, Chile: Literatura Americana Reunida, 1989), 61.

${ }^{10} \mathrm{DGJ}, \mathrm{AGU}$.
} 
After this thorough cleansing of the faculty, the new authorities set out to control university life. Between 1976 and 1977, 793 new faculty members were hired to fill the vacant positions. ${ }^{11}$ This staff, just like any other public servant, had to undergo a "thorough scrutiny of their personal background." ${ }^{2}$ In 1979, a new provision required "qualification for public service," which classified all candidates into three categories of allegiance to the regime according to a background investigation by the armed forces. ${ }^{13}$ Employees from other state branches were transferred to work in the "surveillance" of the institution, while all political and union activities were declared illegal. ${ }^{14}$ In addition, the de facto authorities instituted rules to monitor any suspicious behavior and to punish all alleged dissidents. Students had to request written permission from the Executive Power for all recreational activities as well as sign a "Sworn Declaration of Student Behavior," which included dress codes, restrictions on social gatherings, and standards for addressing authorities within schools. ${ }^{15}$

The new authorities usually depicted these disciplinary measures as providing the conditions for students and faculty to fulfill their "natural" duties, that is, learning and teaching, allegedly suppressed in the late 1960s because of excessive politicization by the predominant leftist groups. However, it is clear that they constituted a major violation of any previous definition of "academic freedom," particularly the right of the institution to define its own goals and to be autonomous from political powers of any kind. In fact, the dismantling of selfgoverning bodies and the authoritarian control of academic life were the main features of this exceptional period in the history of the Universidad de la República. The decision to declare a series of directive posts at the institution as a "particular trust" (that is, politically loyal) and the centralization of decision-making allowed the

${ }^{11}$ Banco Interamericano de Desarrollo (BID), "Proyecto de expansión y mejoramiento de la Universidad de la República" (Montevideo, URY, 1978), 68, Programa Universidad-BID, AGU.

${ }^{12}$ Circular 69/74, June 12, 1974, AGU. Some nonfaculty personnel also agreed with guidelines that the central government issued. See Circular 86/75, May 8, 1975, AGU.

${ }^{13}$ Alonso and Rico, Investigación bistórica vol. 2, 425-29; and Nicolás Duffau, "Prohibido usar el mate: Represión y resistencia, 1973-1985," in Una poderosa máquina opuesta a la ignorancia: 100 años de la Facultad de Agronomía, ed. Esther Ruiz (Montevideo, URY: Facultad de Agronomía, 2007), 333.

14 "Rendición de cuentas y balance de ejecución presupuestal," April 30, 1974, Art. 448, Ley 14189/974, RNLD, 1082-280; and "Reglamento sobre prohibición de actividades política, gremiales o proselitistas de cualquier clase en dependencias universitarias,"June 4 1974, Circular 59/74, AGU.

15 "Reglamento de estudios y declaración jurada de comportamiento estudiantil," March 16, 1976, Circular 50/76, AGU. 
government to strictly supervise all academic activities. ${ }^{16}$ In practice, the rector and the deans, directly appointed by the Executive Power, took on the traditional functions and entitlements of the previously democratically elected councils. ${ }^{17}$ The design of budgetary provisions was additional proof of the authoritarian takeover of formerly autonomous powers, since the university was forced to accept a laundry list of endowments handed down by the Ministry of Education and Culture. ${ }^{18}$ In addition, a Supervisory Commission for Education, made up of high military commanders, had the power to bypass the Ministry in matters as diverse and specific as the terms for examinations and faculty absenteeism. ${ }^{19}$ Direct military control in higher education was also implemented through officers appointed by the Joint Military Command who reported to their respective chains of command. ${ }^{20}$

However, one should not forget that positions of authority remained in civilian hands throughout these years and were often occupied by people with previous experience in (and knowledge of) their workplaces. Most rectors and deans had long academic careers in the different professional schools. Many had been in administrative posts and even been previously elected to governing bodies. Since the late 1950s, some had even resisted the attempt to reform the institution's academic structures and ruling mechanisms as well as voiced opposition to the encroachment of leftist tendencies. Edmundo Narancio, the first rector that the authoritarian government appointed, who was also the Minister of Education and Culture, was a classic example of this route that many took from being part of the university's establishment in the 1950s to confronting the predominant reformist shift of the precoup years, and losing power as a consequence, and then finally ending up as part of the institution's administrative ranks under authoritarian rule. Narancio, in particular, had been displaced as chairman of the History Department in the early 1960s and

\footnotetext{
16 "Rendición de cuentas y balance de ejecución presupuestal."

${ }^{17}$ Decreto 921/973, Oct. 28, 1973, RNLD, 1482-4; and Circulares 36/76, Feb. 19, 1976, and 22/77, Jan. 26, 1977, AGU.

${ }^{18}$ See budgetary provisions for 1977 in Circular 265/76, Dec. 23, 1976, AGU.

${ }^{19}$ See Silvia Campodónico, Ema Julia Massera, and Niurka Sala, Ideología y educación durante la dictadura: Antecedentes, proyectos, consecuencias (Montevideo, URY: Ediciones de la Banda Oriental, 1991), 109; and Ariadna Islas, "La Facultad intervenida, 1973-1985," in Historia y memoria: Medio siglo de la Facultad de Humanidades y Ciencias de la Educación, 1945-1995, ed. Blanca París de Oddone (Montevideo, URY: Universidad de la República, Facultad de Humanidades y Ciencias de la Educación, Departamento de Publicacione, 1995), 90-91.

${ }^{20}$ Las Fuerzas Armadas al Pueblo Oriental, vol. 2, 117, 255-61, and 321-23. See also Circular 144/75, Aug. 28, 1975, AGU.
} 
became an aggressive voice against the alleged violations of standard definitions of "academic freedom." By this he meant the influence of mobilized students in university politics and the collaborative involvement of students, faculty, and university authorities with social movements and protests against an increasingly authoritarian government. ${ }^{21}$

After the coup, these agents had the chance to put their dreams for higher education into practice, particularly to revoke the power of those in the center-left who had sought to alter the institution's traditional power scheme in the 1960s. The result could have been, similar to Brazil at the time, an authoritarian modernization modeled on the United States, of what was a lagging, overpopulated, and underfunded system. ${ }^{22}$ However, the new authorities, both military and civilian, seemed more concerned with cleansing the faculty, controlling the students, and repressing any dissent using their own ideas of "academic freedom" rather than with revamping the institution. This negative reaction might have been their only shared ground. Instead of discussing the university's long-term goals, the new authorities wavered between trying to maintain professional training with limited human and material resources and adapting to the current rules of a liberalized economy, including implementing curricula to satisfy the labor market's shortterm needs, usually under the guidelines of lending organizations such as the Inter-American Development Bank. More often than not, this meant embracing a path that destroyed the modest efforts at modernizing higher education that had been achieved since the end of World War II.

It is often difficult for historians to assess the effect of the past on society's present and future. In my years researching these developments from an academic position in this same institution, I have felt the liberating energy of the student movement that emerged in the early 1980s to counter authoritarianism. Since the beginning of the new democracy in 1985, I have marveled at the university community's enormous efforts to build a different notion of "academic freedom" and a new understanding of the institution's role in society. Mobilization and democratic participation were the defining features of this period. Students, faculty members, and other employees who had been displaced after 1973 were able to return to their positions, and only a few of the new staff, those who had been involved in surveillance activities, were prosecuted. These decisions were aimed at

${ }^{21}$ Carlos Zubillaga, Historia e historiadores en el Uruguay del siglo XX: Entre la profesión y la militancia (Montevideo, URY: Librería de la Facultad de Humanidades y Ciencias de la Educación, 2002), 189-90. For information on other deans and rectors, see Banco Interamericano de Desarrollo, 113-43.

${ }^{22}$ For Brazil, see Rodrigo Patto Sá Motta, As universidades e o regime militar (Rio de Janeiro: Jorge Zahar, 2014). 
giving closure to the authoritarian phase while opening up space to discuss the significance of the university at the global level in a new historical time. However, I cannot end these pages without saying that the legacies of this not-so-distant past still linger, particularly in the limited ability to link our efforts to improve higher education and redefine the meaning of "academic freedom" with important debates about the role of the university in promoting social change.

doi: $10.1017 /$ heq.2018.20

\title{
The Front Rank: On Tenure and the Role of the Faculty in the Defense of Academic Freedom
}

\author{
Hans-Joerg Tiede
}

\begin{abstract}
If teachers do not stand fighting in the front rank for freedom of intelligence, the cause of the latter is well-nigh hopeless, and we are in for that period of intimidation, oppression, and suppression that goes, and goes rightly, by the name of Fascism and Nazi-ism.- John Dewey, "The Crucial Role of Intelligence," Social Frontier
\end{abstract}

Current threats to academic freedom-which include attacks on faculty members and institutions of higher education by individual state legislators and governors as well as the activities of such organizations as Campus Reform and Professor Watchlist that frequently spark harassment campaigns against individual faculty members-have arguably created a climate as hostile to academic freedom in the United States as any in the twentieth century. Circumstances that limited faculty members' ability to defend academic freedom in the mid1930 s, a period of marked hostility to academic freedom, share some similarities to those of today. Most notable among those similarities is the prevalence of contingent faculty, which makes it all the more notable that the earlier period gave rise to the modern tenure system. That tenure helps protect the individual's academic freedom as well as the

Hans-Joerg Tiede is an Associate Secretary, Department of Academic Freedom, Tenure, and Governance at the American Association of University Professors (AAUP). The opinions expressed are those of the author. 